\title{
Review of Sonia Wilson. 2020. Family Language Policy: Children's Perspectives. Palgrave Macmillan. ISBN 978-3-030-52437-1 (eBook)
}

\author{
Anik NANDI \\ Leiden University \\ Leiden, The Netherlands
}

For citation:

Nandi, Anik. 2021. Review of Sonia Wilson. 2020. Family Language Policy: Children's Perspectives. Palgrave Macmillan. Russian Journal of Linguistics 25 (4). 1136-1142. https://doi.org/10.22363/2687-0088-2021-25-4-1136-1142

Рецензия

\section{Рецензия на книгу \\ Sonia Wilson. 2020. Family Language Policy: Children's Perspectives. Palgrave Macmillan. ISBN 978-3-030-52437-1 (eBook)}

Аник НАНДИ

Лейденский университет

Лейден, Нидерланды

\section{Для цитирования:}

Nandi A. Review of Sonia Wilson. 2020. Family Language Policy: Children's Perspectives. Palgrave Macmillan. Russian Journal of Linguistics. 2021. Vol. 25, № 4. P. 1136-1142. https://doi.org/10.22363/2687-0088-2021-25-4-1136-1142

The family has long been considered by sociolinguists as an important construct for intergenerational transmission. Although research on multilingual families is now an ingrained domain of inquiry within social sciences, Family Language Policy (henceforth, FLP) emerged as an independent field only in the past two decades. Initially centred on psycholinguistic aspects of children's language learning, this line of research took a sociolinguistic turn when Lanza (2004), using the tools of discourse analysis, confirmed that parental decisions and strategies often influence young children's bilingual outcomes. Drawing on the Spolskyian (2004) framework that understands language policy as an intersection 
between ideologies, planning and practices, it rapidly became an important field in minority language research taking into account caregivers' visible and invisible language planning measures and literacy-related practices at home to control the family's language ecology (Nandi 2018). Whereas early FLP scholarship centred primarily on the caregivers' role, researchers have increasingly come to appreciate the importance of children's agency by investigating their perceptions about parental language governance and explained how children's experiences in a range of contexts outside the home, such as the school, playground, extracurricular activities and peer groups mediate family's linguistic outcome. However, the emotional wellbeing and experiences of bi(multi)lingual children growing up with linguistically different parents received diminished attention from FLP researchers. Building on the home language practices among French and English transnational families, Wilson in her thought-provoking book spotlights on the school-age heritage language (hence, HL) speakers elaborating on their linguistic lived experiences through a range of original research methods. In the context of migration, HL refers to the language(s) spoken in the home and familial contexts.

This book is the result of a three-year-long investigation. One of the crucial aspects of this monograph is its distinctive structure. Crafted in a systematic manner, this concise (209 pages) but compact volume commences with a Preface outlining its principal objective to shift "the focus away from optimising children's bilingual proficiency, towards understanding what is really happening within transnational families" (p. ix). The volume is divided into five asymmetrically distributed chapters followed by an Appendix section involving the examples of Picture Items for Language Scenarios and Facial Expression Visual Stimuli used by the author during the interviews with children. Finally, it culminates with an index offering an alphabetical roadmap of topics discussed.

In Chapter 1, "Heritage Speakers, FLP and Emotional Challenges," Wilson sets out to sketch a sociolinguistic scene where the affiliates of an intermarriage family "interact and establish language patterns" (p. 1). While discussing their family dynamics, the author underscores the key challenges these parents come across when one of them is inborn of the host country, prompting an unequal power distribution between the competing languages at home because of the anonymous presence of the dominant language in the exterior. Since there is no consensus among FLP scholars about the definition of "family," Wilson limits her study to "a traditional nuclear family structure" and admits that this "may not be representative of other family settings such as same sex unions or adoptive families" (p. 2).

The following section offers a chronological overview of FLP research based on Spolsky's paradigm of what family members perceive about language(s) (ideology), what they plan to do with language(s) (management) and what they actually do (practice) with regard to home language maintenance. There is a noteworthy discussion on these components in this chapter touching upon several key debates around FLP such as whether the caregivers should speak in only one language at home, whether each parent should speak his/her own language 
(one parent, one language or OPOL strategy) or "incorporate the majority language and translanguaging into their practices" (p. 6). Ideologies are pivotal to any language policy. Since bilingual parents tend to transmit their ideologies through their language choices in interaction, parental ideologies in transnational homes "are closely linked to their beliefs about parenting" (p. 14).

Wilson starts the next section by defining what it means to be a heritage language speaker. Although the term 'community language' is often used as a generic term to refer to all non-indigenous languages in the UK, most of which are spoken by immigrant communities, whether long-established or recent (Wei 2018), the author restricts it only for the first-generation migrants and reserves the term HL for second-generation migrants who grew up "acquiring both the minority and majority languages and generally become dominant in the majority language" (p. 16). In the UK geopolitical situation, due to the absence of an overarching institutional language policy towards these languages, HL learning often takes place outside mainstream schooling, sometimes through supplementary or community schools that are often supported on a voluntary basis through a range of grassroots level efforts including community organisations, charities or particular religious groupings (Carruthers \& Nandi 2021). Drawing on various international experiences, the discussion then focuses on the competence levels of HL speakers. The next three subsections look at the HL-speaking "children's emotional, psychological and relational experiences of bilingualism" (p. 17). The final section establishes a connection between FLP and the subjective well-being of family members in transcultural homes. Wilson admits at the outset that well-being is a complex phenomenon to define as it involves various facets of an individual's evaluation of their lived experiences. While using De Houwer's (2013) Harmonious Bilingual Development framework to understand well-being of heritage-languagespeaking families, Wilson concludes that it is difficult to become absolutely neutral about everyone's language choices in the home, and contesting ideologies between family members may create situations of tension, thus impacting negatively on the transnational family's well-being. De Houwer finds the solution in "a child's ability to actively use the HL as the key to achieving harmony within the multilingual family" (p. 27). However, the author finds this argument discriminatory towards children since it will make them somewhat accountable for family's emotional challenges. The section concludes with a reminder that the key objective of the investigation is to "addresses the lack of literature on children's perspectives" (p. 30).

Chapter 2 reports on the research methods used in this study. Since the intention is to analyse individual agency within the FLP, Wilson uses a multiple case study approach. This line of research is considered useful for policy assessment as various cases collectively stipulate patterns of good practice during the implementation of a specific policy or programme providing examples of the policy impact on the ground (Keddie 2006). The study adopts a qualitative research design involving a wide range of data collection tools, such as "semi-structured face-to- 
face interviews, email interviews, recorded observations of family interactions (self-recording in one case) and language portraits" (p. 44). The author notes that the current study is part of a larger body of research comprising an online survey $(n=164)$ where parents from twenty-two French complementary schools around the UK participated. Six families who already took part in the survey were selected as representative case studies. Geographically, they are located in three regions of England including London, South-East England and the West Midlands. Whilst the French parents took part in the face-to-face interviews, their monolingual Englishspeaking counterparts, according to the researcher, were "too inept to discuss bilingual parenting" (p. 45), therefore, email interviews were conducted with this demographic. To access information from the children, the author used a variety of ingenious and original research tools such as semi-structured interviews with visual stimuli and language portraits. Whereas the interviews offered insights on their ideological positioning towards caregivers' language management and everyday language practices, language portraits were useful to understand "each young participant's unique interplay between family, bilingualism and cultural identity" (p. 48). Audio recorded observations from five families (one self-recorded) were also used to validate the claims made during the interviews. Notably, family's selfrecorded data is increasingly getting popular in FLP research since it considers the observations of the participants whose lives are being affected by an intervention or result of the research (see Curdt-Christiansen 2016, Nandi 2017). Thematic analysis was deployed as the medium of data interpretation.

Having discussed the theoretical and methodological assumptions in the first two chapters, Chapter 3 and Chapter 4 present an analysis of the collected data. The wealth of the data offered here will certainly impress the reader. For instance, Chapter 3, "Childhood Experiences of FLP: 6 Case Studies of French Heritage Speakers in England," which is also the longest chapter (94 pages) of this book, offers an extensive account "of family's language practices, parental language management style and methods, and parental language ideologies" (p. 57). Fictitious names have been used to protect the real identity of the respondents. The case examples are divided into various subsections helping the readers to follow the narrative. In addition to the discussion on family members' ideologies, management and practices, each case involves a variety of ancillary components, such as 'Observed Language Practices \& Management,' 'Parental Expectations of Children's HL Proficiency,' 'Non-French Parent's Approach to Bilingual Childrearing,' 'Parental Perception of Children's Attitude' and 'Children's Attitude Towards the HL and Parental Language Management' offering a comprehensive overview of individual family's language ecology. What I particularly missed in this chapter is a section on conclusion cross-referencing between the different case studies presented. It somehow ends abruptly with a quote from the sixth case study. Moreover, the analysis in this chapter sometimes lacks a critical voice due to its descriptive style. 
Chapter 4, "Fostering Harmonious Bilingual Development through Family Language Policy," underlines "the role of language attitudes and preferences in childhood bilingualism and highlight the holistic and individual nature of young heritage speakers' bilingual experiences" (p. 153). This short chapter (18 pages) is distributed between four sections presenting the key themes that appeared in the case studies discussed in the previous chapter. Building on the participants' deposition, the first section titled 'Discussing Family Language Policy with Children' underlines that the heritage-language-speaking parents who often adopt the role of custodians over their children's everyday language conduct towards the minority language, are unaware of their real feelings about these top-down decisions. Therefore, for a harmonious FLP, Wilson argues that the "conversations about parental language planning [are] all the more necessary" in the family (p. 154). The following two sections focus on young HL speakers' attitudes concerning the HL, their language preferences and individual experiences. The data discussed here demonstrates that children as young as six retain a clear awareness of caregivers' language planning strategies. Even though some young HL speakers articulate that their parents' strict FLP sometimes make them feel "annoyed," "sad" or "angry," they are aware of its emotional significance for the French-speaking parent. All the eight children studied also maintain a positive attitude towards their HL and family's bilingualism. While searching for explanations for such positive attitudes, the author argues that French being offered as a modern foreign language in British schools, may influence this behaviour. The final section examines the impact of "imposing" HL-centred FLPs on children. Since each family has its own norms for language use, children's bilingual experiences are also diverse. Wilson notes that strict practices such as prohibiting the use of English while talking to a minority-language parent may provoke negative emotions among children leading to a reduced or minimal communication between them (p. 167). Moreover, parental assumptions about creating the home as a secure place for bilingualism and minority language maintenance, as many FLP studies emphasise including this one, may fail dramatically once the children start making their own language choices. Hence, the author calls for more subtle and flexible attitudes towards HL management from parents to avoid "a conflictual bilingual development" (p. 169).

Chapter 5, "Conclusion," which is also the shortest chapter (5 pages), not only summarises the main findings but reflects upon its wider implications. The author revisits the main research questions and centres the discussion around the emotional consequences of certain FLPs on children growing up in transnational homes. While discussing the implications of this investigation, Wilson cautiously reminds the reader that the eight case studies presented here should not be seen as representative to permit generalisation to other situations. Nonetheless, they provided valuable insights into children's linguistic lived experiences in transcultural homes, whether or not they reflect the general experiences of all HL-speaking youngsters.

In my opinion, the weakest link of this monograph is its analysis part which remains mostly descriptive throughout. For instance, the British parents in this 
study labelled their children's bilingual experience as something "natural" (p. 153), which directly links it to the ideology of linguistic naturalism (Armstrong 2014: 576). Although there are some discussions around ideologies in connection with the data, the concept is rarely problematised. Siblings often play a significant role in influencing children's language choices at home. A further discussion on sibling's agency is expected while studying bilingual children's experiences in FLP. Despite the above observations, a particular compliment should be directed to the author. This book is indisputably an excellent contribution to the contemporary FLP literature, particularly in the context of transnational families where one of the parents is a native speaker of the dominant language. Moreover, within FLP as a growing field, much remains to be explored including the configuration of the notion of 'family' itself. Research in this field has drawn extensively from Western/Northern theoretical frameworks. Therefore, it is high time for FLP researchers to see beyond the westernised paradigm of family as a "nuclear" domain (p. 2). What remains invisible from this perspective, are the realities that have existed and continue to emerge outside the Euro-American settings, particularly in the contexts of the Global South. To understand these dynamics, more crossdisciplinary research comparing the contexts of Global North and South are required.

(C) Anik Nandi, 2021

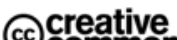
commons

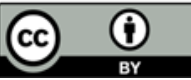

This work is licensed under a Creative Commons Attribution 4.0 International License https://creativecommons.org/licenses/by/4.0/

\section{REFERENCES}

Armstrong, Timothy Currie. 2014. Naturalism and ideological work: How is family language policy renegotiated as both parents and children learn a threatened minority language? International Journal of Bilingual Education and Bilingualism 15(5). 570-585. https://doi.org/10.1080/13670050.2013.860074

Carruthers, Janice \& Anik Nandi. 2021. Supporting speakers of community languages: A case study of policy and practice in primary schools. Current Issues in Language Planning 22 (3). 269-289. https://doi.org/10.1080/14664208.2020.1838748

Curdt-Christiansen, Xiao Lan. 2016. Conflicting language ideologies and contradictory language practices in Singaporean bilingual families. International Journal

of Multilingual and Multicultural Development 37 (7). 694-709. https://doi.org/10.1080/01434632.2015.1127926

De Houwer, Annick. 2013. Harmonious bilingual development: Young families' well-being in language contact situations. International Journal of Bilingualism 19 (2). 169-184. https://doi.org/10.1177/1367006913489202

Keddie, Vince. 2006. Case study method. In Victor Jupp (ed.), The Sage Dictionary of Social Research Method, 20-21. London: Sage. https://doi.org/10.4135/9780857020116.n14

Lanza, Elizabeth. 2004. Language Mixing in Infant Bilingualism: A Sociolinguistic Perspective. Oxford: Oxford University Press. 
Nandi, Anik. 2017. Language policies on the ground: Parental language management in urban Galician homes. $\mathrm{PhD}$ Thesis. Edinburgh: Heriot-Watt University. https://www.ros.hw.ac.uk/handle/10399/3360 (accessed 03 August 2021).

Nandi, Anik. 2018. Parents as stakeholders: Language management in urban Galician homes. Multilingua 37 (2). 201-223. https://doi.org/10.1515/multi-2017-0020

Spolsky, Bernard. 2004. Language Policy. Cambridge: Cambridge University Press.

Wei, Li. 2018. Community languages in late modernity. In James W. Tollefson \& Miguel Pérez-Milans (eds.), The Oxford Handbook of Language Policy and Planning, 591-609. Oxford: Oxford University Press.

\section{Book review history:}

Received: 20 May 2021

Accepted: 20 October 2021

\section{Bionote:}

Anik NANDI (PhD) is a Visiting Researcher at the Leiden University Centre for Linguistics (LUCL), The Netherlands. In 2013-2017 he took part in the COST project New Speakers in a Multilingual Europe and in 2020-2024 in the COST project Language in the Human-Machine Era. Nandi specialises in language policy and literacy practices in multilingual societies. He has published extensively in English, Spanish, Galician and Bengali in several national and international journals.

\section{Contact information:}

Praza da Universidade, 4, Santiago de Compostela, 15782, A Coruña, Spain e-mail: a.nandi@hum.leidenuniv.nl

ORCID: 0000-0001-8254-6637

\section{Сведения об авторе:}

Аник НАНДИ $(\mathrm{PhD})$ - приглашенный научный сотрудник Центра лингвистики Лейденского университета, Нидерланды. Участник Европейских COST проектов "New Speakers in a Multilingual Europe: Opportunities and Challenges" (2013-2017 гг.) и "Language in the Human-Machine Era" (2020-2024 гг). Специализируется на языковой политике и распространении грамотности в многоязычном обществе. Много публикуется на английском, испанском, галисийском и бенгальском языках в журналах национального и международного уровня.

\section{Контактная информация:}

Praza da Universidade, 4, Santiago de Compostela, 15782, A Coruña, Spain e-mail: a.nandi@hum.leidenuniv.nl

ORCID: 0000-0001-8254-6637 